\title{
Comparative analysis of Haemophilus influenzae type b and Escherichia coli J5 lipopolysaccharides
}

\author{
MOLLY R. HILL, K. L. McKINNEY,* M. I. MARKS, † and R. M. HYDE \\ Department of Microbiology and Immunology, University of Oklahoma Health Sciences Centre, P.O. Box \\ 26901. Oklahoma City, Oklahoma 73190, "Hynson, Westcott and Dunning, Becton Dickinson and Company, \\ Charles and Chase Streets, Baltimore, Maryland, 21201 and tDepartment of Pediatrics (Infectious Diseases), \\ 940 N.E. 13th Street, Oklahoma City, Oklahoma, 73126, USA
}

\begin{abstract}
Summary. Haemophilus influenzae type b (HIB) and Escherichia coli J5 (J5) lipopolysaccharides (LPS) were examined to explore the basis of previously observed crossprotection. HIB-LPS and J5-LPS contained ketodeoxyoctonate, glucose, glucoheptose and glucosamine as common carbohydrate moieties, and laurate, myristate, $\beta$ hydroxymyristate and palmitate as common fatty acids, although in different ratios. J5-LPS was five times more lethal than HIB-LPS for chick embryos. Weak serological cross-reactivity was observed by haemagglutination and two-dimensional immunoelectrophoresis. No significant cross-reactivity was demonstrated by enzyme-linked immunosorbent or toxicity-neutralisation assays. The cross-reactivity observed between HIB-LPS and J5-LPS was probably due to common components in the core glycolipid.
\end{abstract}

\section{Introduction}

Haemophilus influenzae type b (HIB) is the leading cause of bacterial meningitis in young infants in the USA; $80 \%$ of the cases occur in infants under 24 months of age (Smith, 1981). Because capsular polysaccharide vaccines have been ineffective in young infants (Parke et al., 1977; Peltola et al., 1977) and the pathogenesis of these infections is incompletely understood, we have studied subcapsular antigens, particularly lipopolysaccharide (LPS), which might contribute to virulence and stimulate protective immunity.

Although gram-negative bacteria are heterogeneous with regard to the $\mathrm{O}$ antigens of LPS, the core region of this molecule appears to be similar in most species (Lüderitz et al., 1966). For this reason, $\mathrm{Re}$ and $\mathrm{Rc}$ mutants have been studied as possible immunogens to protect against various gram-negative infections. The Rc mutant of Escherichia coli $\mathrm{O} 111: \mathrm{B} 4$, designated $\mathrm{J} 5$, has been studied as a possible vaccine against heterologous organisms, such as Klebsiella and Pseudomonas (Ziegler et al., 1973, 1975 and 1982). The J5 mutant, first described by Elbein and Heath (1965), lacks the enzyme uridine diphosphate galactose 4-epimerase, which incorporates galactose into LPS, thus preventing attachment of oligosaccharide chains.

Marks et al. (1982b) prevented death from HIB infection in a mouse model (Marks et al., 1982a) by

Received 10 Jan. 1985; accepted 25 Mar. 85 active immunisation with whole cells of $E$. coli $\mathrm{J} 5$ and by passive immunisation with the corresponding antiserum. The passive protection was abrogated by absorption of the antiserum with J5-LPS. The basis for this cross-protection is believed to be due to biochemical and immunological similarities between HIB-LPS and J5-LPS. The purpose of this investigation was to examine some of these properties and the mechanism whereby heterologous $E$. coli (J5) LPS prevents death due to experimental HIB infection.

\section{Materials and methods}

\section{Bacteria}

Haemophilus influenzae type b strain 579, a $\beta$-lactamase producer, was isolated from the cerebrospinal fluid of a child with meningitis and maintained frozen at $-70^{\circ} \mathrm{C}$. Escherichia coli J5, maintained on Trypticase Soy Agar (TSA) slants at $25^{\circ} \mathrm{C}$, was derived from a strain originally obtained from Dr E. Heath, Johns Hopkins Hospital, Baltimore, MD and generously provided by $\mathrm{Dr}$ A. I. Braude, San Diego, CA.

\section{Isolation and purification of lipopolysaccharides}

HIB-LPS was extracted by the method of Westphal and Jann (1965) from cells grown on chocolate agar. J5LPS was extracted by the method of Galanos et al. (1969) from cells grown on TSA. The final products were washed with phosphate-buffered saline (PBS) by ultracentrifugation and resuspended in PBS. For biochemical determina- 
tion, LPS samples were further purified by treatment with RNAase, DNAase, and trypsin $(1 \mathrm{mg} / 10 \mathrm{mg}$ of carbohydrate). LPS $(5-10 \mathrm{mg})$ was then applied to a $1.6 \mathrm{~cm} \times 50$ cm Sepharose C1-6B column and eluted with $10 \mathrm{~mm}$ EDTA-25mM Tris buffer, $p \mathrm{H} \mathrm{7.5.} \mathrm{The} \mathrm{column} \mathrm{was}$ calibrated with phenol red (mol. wt 1000) and dextran blue (mol. wt $\left.2 \times 10^{6}\right)$. Alternate fractions were assayed for protein and total carbohydrate. Fractions containing LPS eluted in the void volume, confirmed by fused rocketimmunoelectrophoresis with specific rabbit LPS antiserum. These fractions were pooled and dialysed against three changes of distilled water to remove EDTA-Tris.

\section{Biochemical determinations}

Total carbohydrate was measured by the phenolsulphuric acid method of Dubois et al. (1956) with dextrose as the standard. Absorbance was determined at $485 \mathrm{~nm}$ and concentration was determined from a standard curve. Protein content was measured by the method of Bradford (1976) with the Bio-Rad Protein Assay kit (Bio-Rad, Richmond, CA). Concentration of protein was estimated from a standard curve, with bovine $\gamma$-globulin (Bio-Rad) as the standard. The amount of ketodeoxyoctonate (KDO) in LPS was determined by the method of Weissbach and Hurwitz (1959) as modified by Osborn (1963). Absorbance of the thiobarbituric acid chromophores was determined at $548 \mathrm{~nm}$ and the concentration determined from a standard curve with KDO (Sigma, St Louis, MO) as the standard. The presence of DNA in the LPS samples was determined by the method of Burton (1956). Absorbance was measured at $600 \mathrm{~nm}$ and concentrations were determined from a standard curve with DNA (E. coli strain B, Sigma) as the standard.

\section{Gas-liquid chromatographic analysis of carbohydrate and fatty acids}

All analyses were performed in a Hewlett Packard $5880 \mathrm{~A}$ gas chromatograph equipped with a flame ionisation detector. Analysis of carbohydrates present in LPS preparations was performed by conversion of sugars to alditol acetate derivatives (Sawardeker et al., 1965; Griggs et al., 1971) with some modifications. Each sample was hydrolysed with $0.2 \mathrm{~N} \mathrm{HCl}$ for $72 \mathrm{~h}$ at $100^{\circ} \mathrm{C}$. The $\mathrm{HCl}$ was removed by rotary evaporation and $0.5 \mathrm{ml}$ of $0.6 \mathrm{~N}$ sodium borohydride (Sigma) in $1 \mathrm{~N} \mathrm{NH}_{4} \mathrm{OH}$ was added and stirred at room temperature for $1 \mathrm{~h}$. Acetic acid was added drop by drop to destroy excess $\mathrm{NaBH}_{4}$ and the samples dried by rotary evaporation. Methanol containing acetic acid $0.5 \%$ was added and the samples were dried by rotary evaporation. This step was repeated, followed by three washes with methanol. The samples were extracted with ethanol and washed six times with methanol-acetic acid and three times with methanol. Acetylation was performed with $1.0 \mathrm{ml}$ of acetic anhydride and 10 $\mu \mathrm{l}$ of pyridine at $80^{\circ} \mathrm{C}$ for $2 \mathrm{~h}$. Toluene was added to the samples which were then dried by rotary evaporation. This step was repeated three times. The samples were then suspended in water and chloroform, with the acetates recovered from the chloroform, and 1-3 $\mu$ l used for the analysis. Analysis was performed on a $3 \mathrm{ft} \times 2 \mathrm{~mm}$ ID glass column packed with SP-2340 $3 \%$ on $100 / 120$ Supelcoport (Supelco, Bellefonte, PA) with nitrogen as the carrier gas at a flow rate of $50 \mathrm{ml} / \mathrm{min}$. The column temperature was programmed to run from $180^{\circ} \mathrm{C}$ to $240^{\circ} \mathrm{C}$ at $2^{\circ} \mathrm{C} / \mathrm{min}$ with a $6 \mathrm{~min}$ initial hold. Reference standards of alditol acetate mixtures (Supelco) were used to determine relative retention times. Individual peaks were measured as the area under the peak, and the percentage of the total area represented by each peak was determined.

Analysis of fatty acids was performed by converting them to methyl esters as described by Metcalfe et al. (1966) and modified by Moss et al. (1974). Analysis was performed on a $10 \mathrm{ft} \times 2 \mathrm{~mm}$ ID $\times \frac{1}{4}$ in OD glass column packed with SP-2100 DOH 3\% on 100/120 Supelcoport (Supelco) with nitrogen as the carrier gas at a flow rate of $20 \mathrm{ml} / \mathrm{min}$. The column temperature was programmed to increase from $150^{\circ} \mathrm{C}$ to $225^{\circ} \mathrm{C}$ at $4 \mathrm{C} / \mathrm{min}$. Reference standards of methyl esters (Supelco) were used to determine relative retention times. Peaks were measured as described above.

\section{Preparation of antisera}

Antisera against whole bacterial cells and LPS vaccines were prepared in New Zealand white rabbits. All injections were intravenous. Antisera to whole cell HIB and J5 were prepared with formalin-killed cells $\left(1 \times 10^{9}\right)$ for the initial immunisation, followed by four, weekly booster immunisations with $1 \times 10^{9}$ live cells. Antisera to HIBLPS and J5-LPS were prepared with LPS conjugated to methylated bovine serum albumin at a ratio of $1: 1$. Rabbits were immunised with five weekly increasing doses (5-250 $\mu \mathrm{g}$ of carbohydrate). All rabbits were bled 5 days after the last injection.

\section{Chick-embryo toxicity and neutralisation}

Purified antigens were examined for toxicity in 10-dayold white leghorn chick embryos (Horsfall and Tamm, 1965). Graded doses of each antigen $(100 \mu \mathrm{l})$ were injected on to the chorio-allantoic membrane and the eggs were examined 24 and $48 \mathrm{~h}$ later for death of the embryo. The LD50 was determined by probit analysis. Neutralisation of toxicity by heat-inactivated antisera was measured by mixing a constant amount of antiserum with graded doses of antigen. The mixtures were incubated for $30 \mathrm{~min}$ at $37^{\circ} \mathrm{C}$ before inoculation into eggs. Eggs were examined as above and significant neutralisation was determined by the $\chi^{2}$ test.

\section{Serological techniques}

Haemagglutination assays were performed according to the method of Neter et al. (1956). The titre recorded was the highest serum dilution that gave a $1+$ agglutination pattern.

Enzyme-linked immunosorbent assays (ELISA) were 
performed according to the method of Engvall and Perlmann (1972). Polyvinyl chloride microtitration plates (Dynatech, Alexandria, VA) were coated with $50 \mu \mathrm{l}$ of

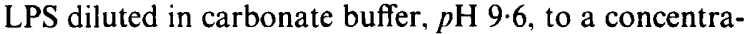
tion of carbohydrate $50 \mu \mathrm{g} / \mathrm{ml}$. The plates were incubated at $37^{\circ} \mathrm{C}$ for $6 \mathrm{~h}$ and then overnight at $4^{\circ} \mathrm{C}$. The test sera were diluted in PBS-Tween $20(0.05 \% \mathrm{v} / \mathrm{w}), p \mathrm{H} \mathrm{7.4}$, and 50 $\mu \mathrm{l}$ was added to each well. The plates were incubated at $37^{\circ} \mathrm{C}$ for $2.5 \mathrm{~h}$ and then washed with PBS-Tween 20 . The enzyme conjugate, goat anti-rabbit IgG (Fc portion) or IgM horseradish peroxidase (Sigma), was diluted 1 in 1000 in PBS-Tween. After adding $50 \mu 1$ to each well, the plates were incubated for $1.5 \mathrm{~h}$ at $37^{\circ} \mathrm{C}$ and then washed with PBS-Tween 20 . The substrate, $40 \mathrm{mg}$ of $o$-phenylenediamine (Sigma), was dissolved in $0 \cdot 1 \mathrm{M}$ citrate buffer, $p \mathrm{H}$ $5 \cdot 0$, and $50 \mu \mathrm{l}$ were added to each well. After incubating for $1 \mathrm{~h}$ at room temperature, the reactions were stopped by adding $25 \mu \mathrm{l}$ of $2.5 \mathrm{M} \mathrm{H}_{2} \mathrm{SO}_{4}$. The absorbance at $490 \mathrm{~nm}$ was determined with a Biotech Model ELISA reader and compared with values obtained with normal serum.

The two-dimensional immunoelectrophoretic (IEP) techniques used were those described by Axelsen et al. (1973), with 1\% low endo-osmosis agarose (FMC, Rockland, MD).

\section{Results}

\section{Biochemical analysis}

Application of HIB-LPS or J5-LPS to the Sepharose C1-6B column resulted in the major carbohydrate peak eluting with the void volume, indicating a large molecule with a mol. wt of $c$. $2 \times 10^{6}$. These fractions formed strong immunoprecipitation lines against specific rabbit LPS antisera in fused rocket immunoelectrophoresis and were pooled separately for the biochemical analysis. Because these pooled fractions were not lyophilysed, percentages of protein and KDO were based on carbohydrate content instead of dry weight.

$H I B-L P S$. The Westphal extract of HIB-LPS contained no detectable DNA and $41 \mu \mathrm{g}$ of nondialysable protein, which represented $5.9 \%$ of the amount of carbohydrate (table I); the amount of KDO, $18 \mu \mathrm{g}$, was $2.5 \%$ of the carbohydrate content. The GLC analysis of HIB-LPS, with mannose as the internal standard, revealed the presence of galactose, glucose, glucoheptose and glucosamine in ratios of $2: 4: 2: 1$ (fig. 1). A peak at $19.04 \mathrm{~min}$ could not be identified by comparison with relative retention times of known hexoses or other available heptoses such as sedoheptulose or mannoheptulose. Different hydrolytic conditions did not alter the presence or size of this peak. Glucose was the most abundant hexose $(36.8 \%)$, while galactose $(18.3 \%)$ and glucoheptose $(16.8 \%)$ were present in approximately equal amounts (table II). A small amount of
Table I. Biochemical composition of $H$. influenzae type b and $E$. coli J5 LPS extracts employed for GLC analysis

\begin{tabular}{l|cccc}
\hline Extract & $\begin{array}{c}\text { Carbohydrate } \\
(\mu \mathrm{g})\end{array}$ & $\begin{array}{c}\text { KDO } \\
(\mu \mathrm{g})\end{array}$ & $\begin{array}{c}\text { Protein } \\
(\mu \mathrm{g})\end{array}$ & DNA \\
\hline HIB-LPS (Westphal) & 694 & 18 & 41 & N.D. \\
J5-LPS (Galanos) & 252 & 188 & 23 & N.D. \\
\hline
\end{tabular}

N.D. $=$ not detected at a sensitivity of DNA $1.4 \mu \mathrm{g} / \mathrm{ml}$.

Table II. GLC analysis of $H$. influenzae type b LPS (Westphal) carbohydrates and fatty acids

\begin{tabular}{|c|c|c|c|c|}
\hline $\begin{array}{c}\text { Peak } \\
\text { no. }\end{array}$ & $\begin{array}{l}\text { Retention } \\
\text { time } \\
\text { (min) }\end{array}$ & Constituent & Area & $\begin{array}{c}\text { Percentage } \\
\text { of } \\
\text { total area }\end{array}$ \\
\hline & \multicolumn{3}{|c|}{ Carbohydrates } & \\
\hline 1 & 13.43 & Mannose & 419 & N.C. \\
\hline 2 & $14 \cdot 64$ & Galactose & 318 & $18 \cdot 3$ \\
\hline 3 & 16.48 & Glucose & 637 & $36 \cdot 8$ \\
\hline 4 & $19 \cdot 04$ & Unknown & 338 & $19 \cdot 5$ \\
\hline 5 & 23.05 & Glucoheptose & 292 & $16 \cdot 8$ \\
\hline 6 & $35 \cdot 16$ & Glucosamine & 148 & $8 \cdot 5$ \\
\hline & & Fatty acids & & \\
\hline 1 & $5 \cdot 13$ & Laurate & 1354 & 0.7 \\
\hline 2 & $8 \cdot 83$ & Myristate & 151370 & $80 \cdot 1$ \\
\hline 3 & $10 \cdot 10$ & 12-Methylmyristate & 11694 & $6 \cdot 2$ \\
\hline 4 & $11 \cdot 06$ & 3-Hydroxymyristate & 14864 & $7 \cdot 8$ \\
\hline 5 & $12 \cdot 83$ & Palmitate & 2725 & $1 \cdot 4$ \\
\hline 6 & 16.52 & Oleate & 6857 & $3 \cdot 6$ \\
\hline 7 & $17 \cdot 17$ & Stearate & 16224 & N.C. \\
\hline
\end{tabular}

N.C. $=$ not calculated.

glucosamine $(8 \cdot 5 \%)$, a core component, was also detected.

Specific fatty acids were identified by GLC analysis with stearate as the internal standard (fig. 1). Because no authentic standard was available, 3hydroxymyristic acid was identified by its presence in Salmonella minnesota Re595 LPS (kindly supplied by Dr R. E. McCallum). Myristate was the most abundant fatty acid detected $(80 \cdot 1 \%)$, followed by 3-hydroxymyristate $(7.8 \%)$, and 12 methyl myristate $(6.2 \%)$ (table II). Peaks at 8.02 , 9.67 , and $19.36 \mathrm{~min}$ could not be identified by available fatty acid standards.

J5-LPS. The Galanos extract of J5-LPS was void of detectable DNA, but contained $23 \mu \mathrm{g}(9.1 \%)$ of non-dialysable protein (table I). Contrary to the findings with the HIB-LPS extracts, there was a considerable amount of KDO (188 $\mu \mathrm{g})$ compared with the total amount of carbohydrate $(252 \mu \mathrm{g})$. In 


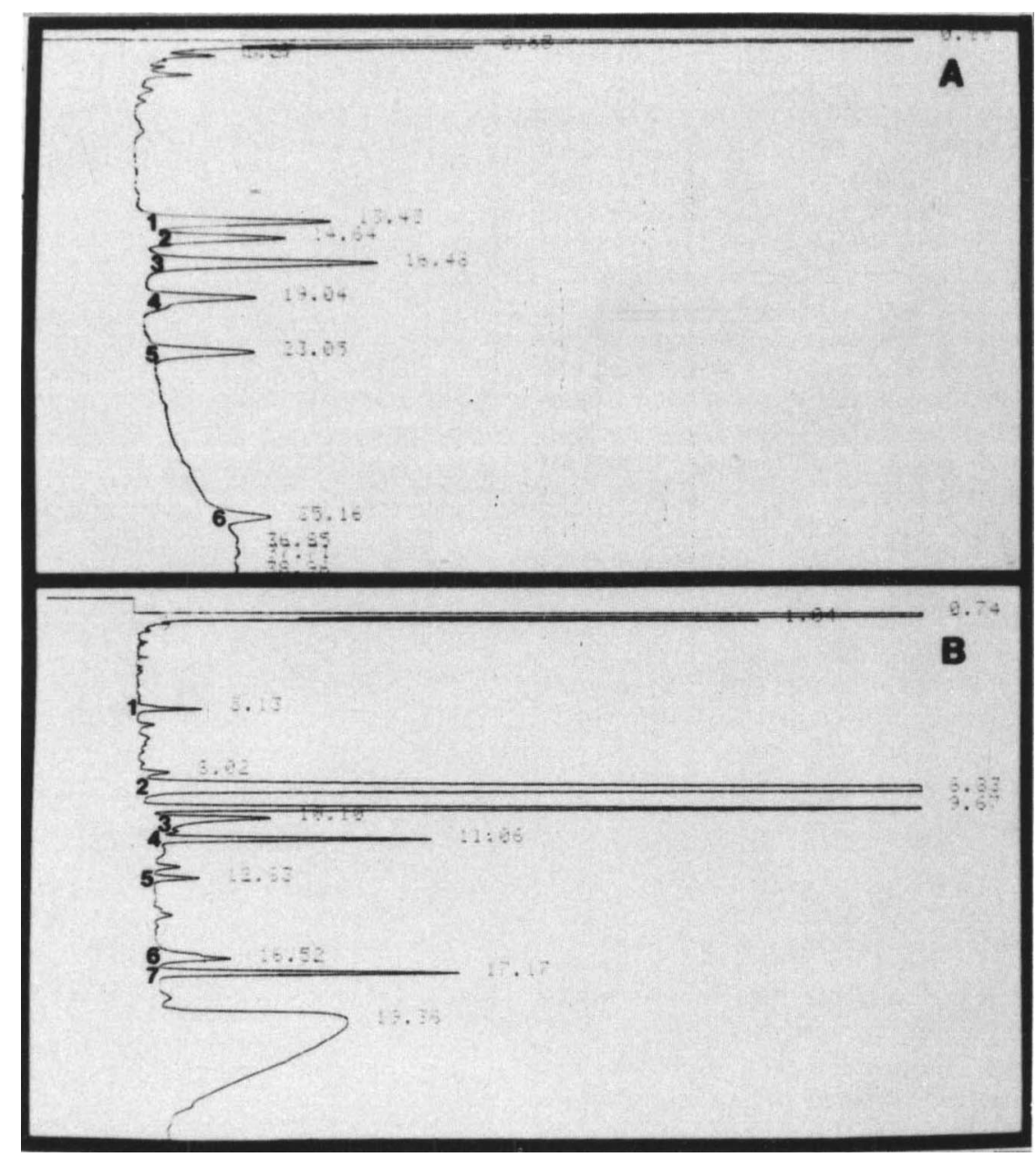

Fig. 1. GLC analysis of $H$. influenzae type b LPS (Westphal) carbohydrates (A) and fatty acids (B).

Table III. GLC analysis of E. coli J5-LPS (Galanos) carbohydrates and fatty acids

\begin{tabular}{|c|c|c|c|c|}
\hline $\begin{array}{c}\text { Peak } \\
\text { no. }\end{array}$ & $\begin{array}{l}\text { Retention } \\
\text { time } \\
\text { (min) }\end{array}$ & Constituent & Area & $\begin{array}{l}\text { Percentage } \\
\text { of } \\
\text { total area }\end{array}$ \\
\hline \multicolumn{5}{|c|}{ Carbohydrates } \\
\hline 1 & $13 \cdot 50$ & Mannose & 821 & N.C. \\
\hline 2 & 16.57 & Glucose & 96 & $4 \cdot 1$ \\
\hline 3 & $19 \cdot 06$ & Unknown & 1616 & $69 \cdot 7$ \\
\hline 4 & $23 \cdot 11$ & Glucoheptose & 150 & $6 \cdot 6$ \\
\hline 5 & $35 \cdot 15$ & Glucosamine & 455 & $19 \cdot 6$ \\
\hline \multicolumn{5}{|c|}{ Fatty acids } \\
\hline 1 & $5 \cdot 12$ & Laurate & 14046 & $39 \cdot 4$ \\
\hline 2 & 8.65 & Myristate & 17910 & $50 \cdot 2$ \\
\hline 3 & $11 \cdot 21$ & 3-Hydroxymyristate & 2002 & $5 \cdot 6$ \\
\hline 4 & $12 \cdot 80$ & Palmitate & 1713 & $4 \cdot 8$ \\
\hline 5 & $17 \cdot 17$ & Stearate & 31772 & N.C. \\
\hline
\end{tabular}

N.C. $=$ not calculated. the GLC carbohydrate analysis (fig. 2), small amounts of glucose $(4 \cdot 1 \%)$ and glucoheptose $(6 \cdot 6 \%)$ were recovered, while a large percentage of glucosamine was found $(19.6 \%$ ) (table III). Large amounts of the unknown peak no. 4 were present $(69.7 \%)$.

In the GLC fatty-acid analysis (fig. 2), myristate $(50.2 \%)$ and laurate $(39.4 \%)$ were the predominant fatty acids, while small amounts of 3-hydroxymyristate $(5.6 \%)$ and palmitate $(4.8 \%)$ were also detected (table III). Several peaks were present that were unidentifiable $(6 \cdot 41,7 \cdot 98,9 \cdot 56$, and $23.29 \mathrm{~min})$.

\section{Toxicity}

J5-LPS was more toxic in chick embryos (LD50 $100 \mathrm{ng}$ of carbohydrate) than HIB-LPS (LD50 512 ng of carbohydrate) (table IV). A significant reduction in lethality of HIB-LPS $(p \leqslant 0.05)$ occurred only when it was neutralised by HIB-LPS antiserum 


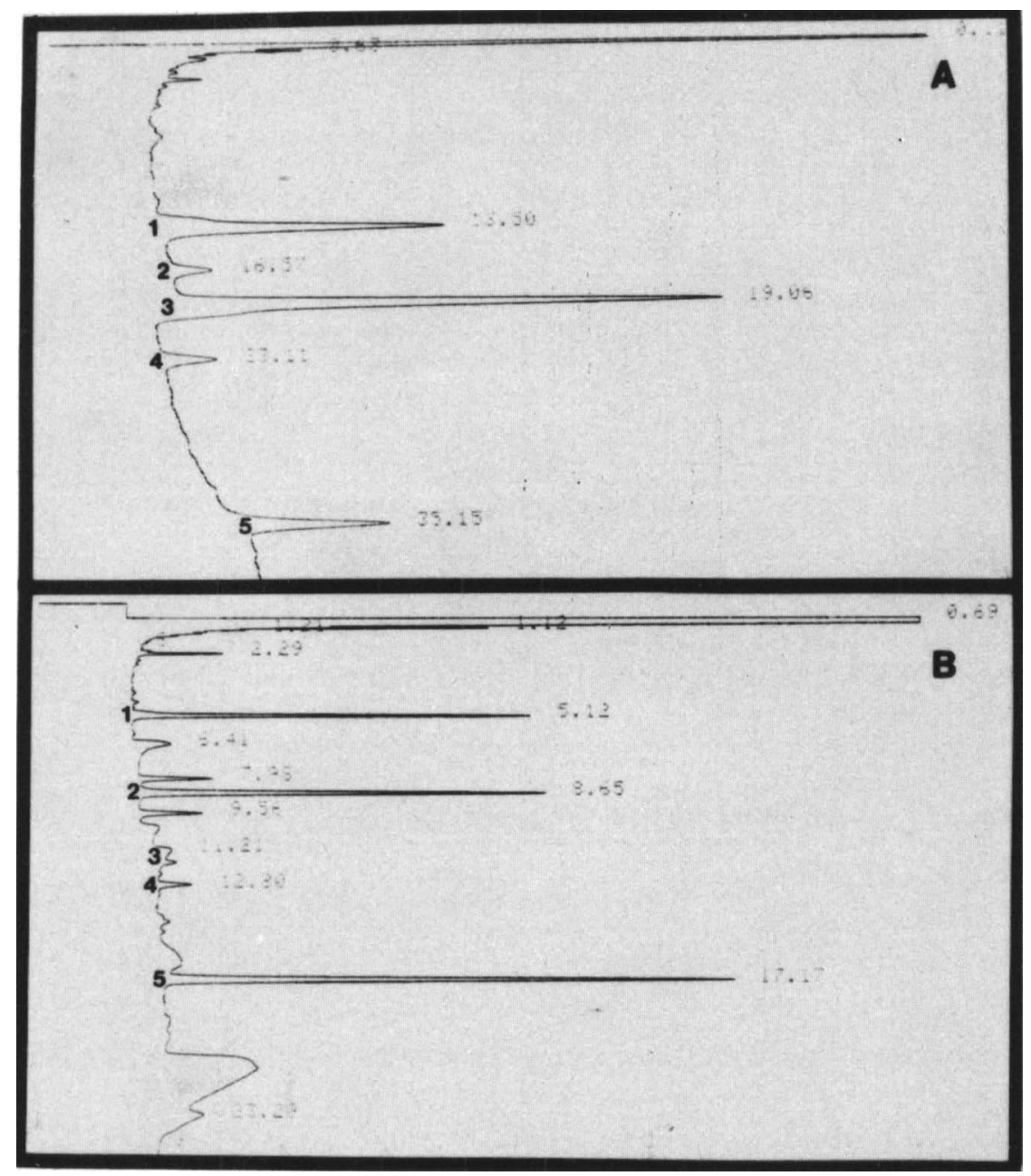

Fig. 2. GLC analysis of E. coli J5-LPS carbohydrates (A) and fatty acids (B).

Table IV. Toxicity of $H$. influenzae type b and $E$. coli $\mathrm{J} 5$ LPS extracts in chick embryos

\begin{tabular}{c|cr}
\hline & \multicolumn{2}{|c}{$\begin{array}{c}\text { Number of embryos killed/ } \\
\text { number tested with }\end{array}$} \\
\hline (ng of carbohydrate) & HIB-LPS* & J5-LPS $\dagger$ \\
\hline 10000 & $18 / 19$ & $15 / 15$ \\
1000 & $40 / 45$ & $14 / 15$ \\
100 & $24 / 50$ & $27 / 40$ \\
10 & $0 / 10$ & $5 / 20$ \\
1 & $0 / 10$ & $0 / 10$ \\
\hline
\end{tabular}

* LD50 $=512 \mathrm{ng}$ (determined by probit analysis).

$\dagger \mathrm{LD} 50=100 \mathrm{ng}$ (determined by probit analysis). (table V). Similarly, J5-LPS toxicity was neutralised only by J5-LPS antiserum.

\section{Haemagglutination assay}

The haemagglutination assay was used to examine cross-reactivity between HIB-LPS and J5-LPS (table VI). Both whole-cell HIB and HIB-LPS antisera had titres of 128 against HIB-LPS coated cells. However, a 4- to 8-fold decrease occurred when the antiserum was tested against J5-LPScoated cells. Similar reductions in titre were seen when whole-cell J5 and J5-LPS antisera were examined. 
Table V. Neutralisation of $H$. influenzae type b and E. coli J5-LPS chickembryo toxicity with specific rabbit antisera

\begin{tabular}{lc|cccc}
\hline & & \multicolumn{3}{|c}{ Number of embryos killed/number tested with } \\
\cline { 3 - 7 } Antigen & $\begin{array}{c}\text { Carbohydrate } \\
\text { dose }(\mu \mathrm{g})\end{array}$ & $\begin{array}{c}\text { no serum added } \\
\text { to LPS } \\
\text { (controls) }\end{array}$ & $\begin{array}{c}\text { normal rabbit } \\
\text { serum added to } \\
\text { LPS (controls) }\end{array}$ & HIB-LPS & J5-LPS \\
\hline HIB-LPS & 1 & $30 / 35$ & $10 / 11$ & $7 / 40^{*}$ & $14 / 25$ \\
HIB-LPS & $0 \cdot 1$ & $13 / 20$ & $10 / 13$ & $0 / 10^{*}$ & $7 / 15$ \\
J5-LPS & 10 & $5 / 5$ & $\ldots$ & $\ldots$ & $1 / 11^{*}$ \\
J5-LPS & 1 & $14 / 15$ & $13 / 15$ & $25 / 30$ & $8 / 30^{*}$ \\
J5-LPS & $0 \cdot 1$ & $6 / 10$ & $1 / 6$ & $6 / 15$ & $0 / 10^{*}$ \\
\hline
\end{tabular}

* $P$ value $<0.05$ as determined by $\chi$-square analysis, when compared with controls that received LPS without serum.

Table VI. $H$. influenzae type b LPS and $E$. coli J-5 LPS cross-reactivity by hemagglutination assay

\begin{tabular}{lc|r}
\hline Rabbit serum tested & $\begin{array}{c}\text { Antigen coating } \\
\text { sheep RBCs }\end{array}$ & Titre \\
\hline Anti-whole cell HIB & HIB-LPS & 128 \\
& J5-LPS & 16 \\
Anti-HIB-LPS & HIB-LPS & 128 \\
& J5-LPS & 32 \\
Anti-whole cell $E$. coli J5 & HIB-LPS & 4 \\
& J5-LPS & 128 \\
Anti-J5-LPS & HIB-LPS & 4 \\
Normal rabbit serum & J5-LPS & 32 \\
& HIB-LPS & N.D. \\
& J5-LPS & N.D. \\
\hline
\end{tabular}

N.D. $=$ not detected.

\section{Two-dimensional immunoelectrophoresis}

HIB-LPS and J5-LPS were examined by IEP with various rabbit antisera against HIB and J5 antigens to determine whether any differences existed between the LPS immunoprecipitation patterns of these extracts and to detect any cross-reactivity. The immunoprecipitation patterns of HIB-LPS and J5LPS were similar (fig. 3). Both exhibited a peak above the antigen well that fused with a peak that migrated towards the anode. No cross-reactivity was detected with heterologous antisera but both anti-HIB-LPS and anti-J5-LPS sera reacted weakly with $S$. minnesota Re595 LPS (kindly supplied by Dr R. E. McCallum). Re595 LPS is a Re mutant containing only KDO and lipid A.
Table VII. IgG and IgM titres of rabbit antisera to specific antigens as determined by ELISA

\begin{tabular}{|c|c|c|c|c|c|c|}
\hline \multirow{3}{*}{$\begin{array}{l}\text { Coating } \\
\text { antigen }\end{array}$} & \multicolumn{4}{|c|}{ Titre of antiserum against } & \multirow{2}{*}{\multicolumn{2}{|c|}{$\begin{array}{c}\text { Titre of } \\
\text { normal rabbit } \\
\text { serum (control) }\end{array}$}} \\
\hline & \multicolumn{2}{|c|}{ HIB-LPS } & \multicolumn{2}{|c|}{ J5-LPS } & & \\
\hline & IgG & IgM & IgG & IgM & $\operatorname{IgG}$ & $\operatorname{IgM}$ \\
\hline HIB-LPS & 625 & 625 & $<5$ & 5 & $<5$ & $<5$ \\
\hline J5-LPS & $<5$ & 5 & 125 & 125 & $<5$ & $<5$ \\
\hline
\end{tabular}

\section{Elisa}

ELISA was also used to test for cross-reactivity between HIB-LPS and J5-LPS (table VII). Minimal IgM cross-reactivity, and no IgG cross-reactions were detected.

\section{Discussion}

The purpose of this study was to examine the basis for J5-LPS cross-protection in HIB infection (Marks et al., 1982b). HIB-LPS and E. coli J5-LPS extracts were, therefore, examined for biochemical content, toxicity, and serologic cross-reactivity.

In comparing HIB-LPS with J5-LPS biochemically, one obvious difference was the amount of KDO present. J5-LPS contained KDO $74 \%$ based on the carbohydrate content, while HIB-LPS contained $2.6 \%$. In the GLC carbohydrate analysis, HIB-LPS and J5-LPS possessed similar carbohydrates, except for the absence of galactose in $\mathrm{J} 5$ LPS, but in different relative amounts. These carbo- 
A
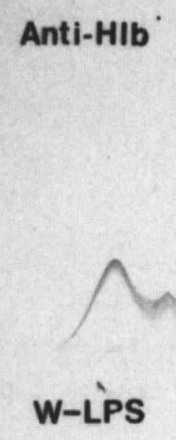

Anti-J5

J5-LPS

c

\section{Anti-HIb-LPS}

4

\section{W-LPS}

Anti-J5-LPS

J5-LPS
B

D

Fig. 3. Comparison of two-dimensional immunoelectrophoresis patterns of $H$. influenzae type b LPS and $E$. coli J5-LPS antisera: gel A-HIB-LPS vs. whole-cell HIB antiserum; gel B-HIB-LPS vs. HIB-LPS antiserum; gel C-J5-LPS vs. whole-cell J5 antiserum; gel D-J5-LPS vs. J5-LPS antiserum.

hydrates were glucose, glucoheptose, and glucosamine. In the lipid analyses, similar fatty acids were found but the percentages again were different. In J5-LPS, myristate and laurate were most abundant, while in HIB-LPS, myristate was the predominant fatty acid. Thus, the lipid-A region of HIB-LPS and J5-LPS both contain similar fatty acids. A Galanos extract of HIB-LPS was also analysed biochemically. No significant differences were found in any of the biochemical analyses (data not shown).

Toxicity of the LPS preparations determined in chick embryos after initial attempts in CF1 mice indicated LD50 values above $50 \mathrm{mg} / \mathrm{kg}$ for HIBLPS. This method was used because chick embryos are sensitive to extremely small quantities of endotoxin. HIB-LPS was approximately five times less toxic than J5-LPS. Raichvarg et al. (1981) reported that LPS from $H$. influenzae type a had an LD50 of $26.5 \mathrm{mg} / \mathrm{kg}$ in mice and the lipid-A fraction had an LD50 of more than $50 \mathrm{mg} / \mathrm{kg}$. Thus, it seems that $H$. influenzae LPS may be generally less toxic than LPS from Enterobacteriaceae. The lipid-A region is 
responsible for the toxicity of LPS (Galanos et al., 1971) and the ester-linked fatty acids are known to be important in the degree of endotoxocity (Rietschel et al., 1975). Even though HIB-LPS and J5LPS have similar fatty acids, the quantity and arrangement may be important in determining certain biological activities.

The presence of common antigenic determinants between HIB-LPS and J5-LPS was examined by several different methods. HIB-LPS and J5-LPS antisera were unable to bind significantly (ELISA) or neutralise (chick embryo toxicity) heterologous LPS. There was no visible immunoprecipitation in IEP when HIB-LPS and J5-LPS antisera were tested against heterologous LPS. It is possible that J5-LPS, a rough LPS, may not precipitate as well as an LPS with an intact $O$ antigen. This is made evident by an increase in solubility after conjugating J5-LPS with methylated BSA. In contrast, HIB antiserum was four- to eight-fold more potent than J5 antiserum in agglutinating heterologous LPScoated sheep red-blood cells. This may indicate that J5-LPS induces an antibody that reacts with a site on HIB-LPS, such as a core component, that is less accessible. HIB-LPS may also induce small amounts of core antibody that react with J5-LPS. It is unlikely that this reaction is due to antibody against outer-membrane proteins, because when HIB-LPS was tested against a HIB outer-membrane-protein preparation in two-dimensional IEP, no immunoprecipitant lines were observed (not shown). Some evidence to implicate core antibody was demonstrated by a weak reaction of both HIBLPS and J5-LPS antisera in two-dimensional IEP with the same immunoprecipitation pattern against S. minnesota Re595 LPS, which consists only of KDO and lipid A (not shown). Thus, the weak serological cross-reactivity seen with HIB-LPS and J5-LPS is probably due to a common immunodeterminant group in the core glycolipid. A recent report has shown that lipid A-specific monoclonal anti-

\section{REFERENCES}

Axelsen N H, Kroll J, Weeke B 1973 A manual of quantitative immunoelectrophoresis. Methods and applications. Scandinavian Journal of Immunology, 2 Suppl 1:15-83.

Bradford M M 1976 A rapid and sensitive method for the quantitation of microgram quantities of protein utilizing the principle of protein-dye binding. Analytical Biochemistry 72: 248-254.

Burton K 1956 A study of the conditions and mechanism of the diphenylamine reaction for the colorimetric estimation of deoxyribonucleic acid. Biochemical Journal 62:315-323. bodies to J5-LPS can be produced by immunising animals with whole heat-killed J5 cells. These antibodies cross-reacted with LPS from various gram-negative bacteria, including $S$. minnesota Re595 and clinical isolates of Pseudomonas aeruginosa (Mutharia et al., 1984). Other anti-J5 monoclonal antibodies have been produced that crossreact with clinical isolates of Klebsiella pneumoniae, Pseudomonas sp. and Proteus sp. (Nelles and Niswander, 1984). Studies by Mullan et al. (1974) have shown that lipid A is not sufficiently exposed on the intact organism for antibody to be attached. Likewise, the antigenic determinants of lipid $\mathrm{A}$ and core glycolipid are distinct, presumably because of the masking effect of KDO (Johns et al., 1977). However, since HIB-LPS has very little KDO, another core sugar, such as glucoheptose may be immunodominant, or antigenic determinants of the lipid region may be exposed. Flesher and Insel (1978) reported that HIB-LPS contained at least three Oantigenic determinants because of variations in the polysaccharide region. This was determined by haemagglutination and absorption experiments with LPS from all six capsular types (a-f). Our data indicate that there are common determinants in HIB-LPS and J5-LPS in the core region, although the reactivity is very weak. The results from these experiments do not explain the cross-protection previously reported between $E$. coli J5 and HIB infection in mice (Marks et al., 1982b). However, other mechanisms besides biochemical or immunological similarities have not been explored. One such mechanism is enhanced bacterial clearance by opsonisation or a non-specific serum factor induced by immunisation with LPS (G. Dominque, personal communication).

This work was supported in part by the Frontiers of Science Foundation and the Samuel Noble Foundation. The advice and support of Drs J. S. Mayes and R. E. McCallum are greatly appreciated.
Dubois M, Gilles K A, Hamilton J K, Rebers P A, Smith F 1956 Colorimetric method for determination of sugars and related substances. Analytical Chemistry 28:350-356.

Elbein A D, Heath E C 1965 The biosynthesis of cell wall lipopolysaccharide in Escherichia coli. I. The biochemical properties of a uridine diphosphate galactose 4-epimeraseless mutant. Journal of Biological Chemistry 240:19191925.

Engvall E, Perlmann P 1972 Enzyme linked immunosorbent assay, ELISA. III. Quantitation of specific antibodies by enzyme-labeled anti-immunoglobulin in antigen-coated tubes. Journal of Immunology 109: 129-135. 
Flesher A R, Insel R A 1978 Characterization of lipopolysaccharide of Haemophilus influenzae. Journal of Infectious Diseases 138:719-730.

Galanos C, Lüderitz O, Westphal O 1969 A new method for the extraction of $\mathrm{R}$ lipopolysaccharides. European Journal of Biochemistry 9:245-249.

Galanos C, Rietschel E T, Lüderitz O, Westphal O 1971 Interaction of lipopolysaccharides and lipid A with complement. European Journal of Biochemistry 19: 143-152.

Griggs L J et al 1971 Identification and quantitation of alditol acetates of neutral and amino sugars from mucins by automated gas-liquid chromatography. Analytical Biochemistry 43:369-381.

Horsfall F L, Tamm I 1965 Viral and rickettsial infections of man, 4th edn. J. B. Lippincott Co., Philadelphia, PA.

Johns M A, Bruins S C, McCabe W R 1977 Immunization with R mutants of Salmonella minnesota. II. Serological response to lipid A and the lipopolysaccharide of Re mutants. Infection and Immunity 17:9-15.

Lüderitz O, Staub A M, Westphal O 1966 Immunochemistry of $\mathrm{O}$ and $\mathrm{R}$ antigens of Salmonella and related Enterobacteriaceae. Bacteriological Reviews 30:192-255.

Marks M I, Ziegler E J, Douglas H, Corbeil L B 1982a Lethal Haemophilus influenzae type b infection in mice. Infection 10: 261-266.

Marks M I, Ziegler E J, Douglas H, Corbeil L, B Braude A I $1982 b$ Induction of immunity against lethal Haemophilus influenzae type b infection by Escherichia coli core lipopolysaccharide. Journal of Clinical Investigation 69:742-749.

Metcalfe L D, Schmitz A A, Pelka J R 1966 Rapid preparation of fatty acid esters from lipids for gas chromatographic analysis. Analytical Chemistry 38:514-515.

Moss C W, Lambert M A, Merwin W H 1974 Comparison of rapid methods for analysis of bacterial fatty acids. Applied Microbiology 28:80-85.

Mullan N A, Newsome P M, Cunnington P G, Palmer G H, Wilson M E 1974 Protection against gram-negative infections with antiserum to lipid A from Salmonella minnesota R595. Infection and Immunity 10:1195-1201.

Mutharia L M, Crockford G, Bogard W C, Hancock R E W 1984 Monoclonal antibodies specific for Escherichia coli J5 lipopolysaccharide: cross-reaction with other gram-negative bacterial species. Infection and Immunity 45:631-636.

Nelles M J, Niswander C A 1984 Mouse monoclonal antibodies reactive with $\mathrm{J} 5$ lipopolysaccharide exhibit extensive serological cross-reactivity with a variety of gram-negative bacteria. Infection and Immunity 46:677-681.

Neter E, Westphal O, Lüderitz O, Gorzynski E A, Eichenberger E 1956 Studies of enterobacterial lipopolysaccharides. Effect of heat and chemicals on erythrocyte-modifying, antigenic, toxic and pyrogenic properties. Journal of Immunology 76:377-385.

Osborn M J 1963 Studies on the gram-negative cell wall. I. Evidence for the role of 2-keto-3-deoxyoctonate in the lipopolysaccharide of Salmonella typhimurium. Proceedings of the National Academy of Sciences of the USA 50:499-506.

Parke J C, Schneerson R, Robbins J B, Schlesselman J S 1977 Interim report of a field trial of immunization with Haemophilus influenzae type $\mathrm{b}$ and meningococcus group $\mathrm{C}$ capsular polysaccharides in Mecklenburg County, N.C., March 1974-March 1976. Journal of Infectious Diseases, 135(Suppl.), 551-556.

Peltola H, Kayhty H, Sivonen A, Makela P H 1977 Haemophilus influenzae type b capsular polysaccharide in children: a doubleblind field study of 100,000 vaccinees 3 months to 5 years of age in Finland. Pediatrics 60:730-736.

Raichvarg D, Guenounou M, Brossard C, Agneray J 1981 Characteristics of a lipid preparation (Lipid A) from Haemophilus influenzae type A lipopolysaccharide. Infection and Immunity 33:49-53.

Rietschel E T, Galanos C, Lüderitz O 1975 Structure, endotoxicity, and immunogenicity of the lipid A component of bacterial lipopolysaccharides. In: Schlessinger D (ed) Microbiology-1975, American Society of Microbiology, Washington, D.C. pp 307-314.

Sawardeker J S, Sloneker J H, Jeanes A 1965 Quantitative determination of monosaccharides as their alditol acetates by gas-liquid chromatography. Analytical Chemistry 37: 1602-1604.

Smith A L 1981 Haemophilus influenzae. In: Feigin R D, Cherry J D (eds) Textbook of pediatric infectious disease W B Saunders Co., Philadelphia, PA, pp 858-872.

Westphal O, Jann K 1965 Bacterial lipopolysaccharides. Extraction with phenol-water and further applications of the procedure. In: Whistler R L (ed), Methods in carbohydrate chemistry, vol 5. Academic Press, New York, p. 83.

Weissbach A, Hurwitz J 1959 The formation of 2-keto-3deoxyheptonic acid in extracts of Escherichia coli B. Journal of Biological Chemistry 234:705-709.

Ziegler E J, Douglas H, Sherman J E, Davis C E, Braude A I 1973 Treatment of E. coli and Klebsiella bacteremia in agranulocytic animals with antiserum to a UDP-Gal epimerasedeficient mutant. Journal of Immunology 111:433-438.

Ziegler E J, McCutchan J A, Douglas H, Braude A I, 1975 Prevention of lethal Pseudomonas bacteremia with epimerase-deficient E. coli antiserum. Transaction of the Association of American Physicians 88: 101-108.

Ziegler E J et al 1982 Treatment of gram-negative bacteremia and shock with human antiserum to a mutant Escherichia coli. New England Journal of Medicine 307: 1225-1230. 